\title{
Slovenian workers - is it too hot to work?
}

\author{
Tjaša Pogačar, Lučka Kajfež Bogataj \\ University of Ljubljana, Biotechnical Faculty, Jamnikarjeva I0I, 1000 Ljubljana, Slovenia \\ tjasa.pogacar@bf.uni-lj.si; lucka.kajfez.bogataj@bf.uni-lj.si
}

\begin{abstract}
Introduction: Frequency, duration, and intensity of heat waves have increased in Slovenia (and Europe), so the thermal resilience of workers is being addressed in the European Heat-Shield project (Horizon 2020). Methods: Wet bulb globe temperature (WBGT) index has been chosen to assess the thermal load of workers. Air temperature and relative humidity inside the factory are being measured to calculate WBGT, meteorological data were gained from the Celje station. A survey about heat stress impacts was conducted among workers (in the factory, farmers, tourist guides, in publishing house, at faculty). Results: In the factory reached air temperatures in August 2016 to $33^{\circ} \mathrm{C}$, WBGT values were mainly between 20 and $25^{\circ} \mathrm{C}$. Workplace temperature is during summer suitable for less than $5 \%$ workers in the factory and agriculture, and for $20 \%$ office workers. Heat stress has a negative impact on productivity, concentration, and well-being. Thirst, excessive sweating, tiredness, headache, and exhaustion are common (mainly more than $55 \%$ ), some have already experienced worse health problems (nausea, prickly heat, muscle and heat cramps, fainting, heat stroke). Discussion and conclusions: As heat stress is already causing problems, various solutions for its mitigation will be developed and tested in the next step of the Heat-Shield project.

Keywords: heat stress, heat wave, workers, productivity, health, wellbeing
\end{abstract}

$\mathrm{S}$ it states in its Executive Summary, EU funded project Heat-Shield (HS, 2016) addresses the negative impacts of workplace heat stress on the health and productivity of the EU workforce. The main mission of the project is to access the negative impacts of workplace heat stress on the health and productivity of workers in strategic European industries (manufac- 
turing, construction, transportation, tourism and agriculture) and the potential increase of these impacts as climate change progresses. Results of the project should provide the know-how to the European community ranging from the individual citizen to public and private policymakers towards implementing methods and procedures that will secure health and productivity despite aggravated workplace heat levels.

According to World Health Organisation (WHO, 2015), it is anticipated that the rising temperatures in Europe during the $21^{\text {st }}$ century will have significant detrimental impacts on the health of local populations - especially in occupational settings - and, as climate change becomes more prevalent, excess heat-related morbidity and mortality will rise between $3 \%$ and $6 \%$. Air temperatures in Slovenia have already increased more than in average in Europe, for instance in Ljubljana in the period $1961-2011$ by $0.4^{\circ} \mathrm{C}$ per decade, maximum values and summer averages even more (ARSO, 2014). Under the moderate $\mathrm{RCP}_{4.5}$ scenario it can be expected that will the average air temperature in Slovenia in 2011-2040 increase by $1^{\circ} \mathrm{C}$ regarding the period 1981-2010 and by another one degree in the next 30-year period (ARSO, 2016). Also, the number of hot days and heat waves is increasing; one example can be seen in Figure 1, showing the decadal number of days and average maximum air temperature in heat waves in Bilje in the period 1966-2015.

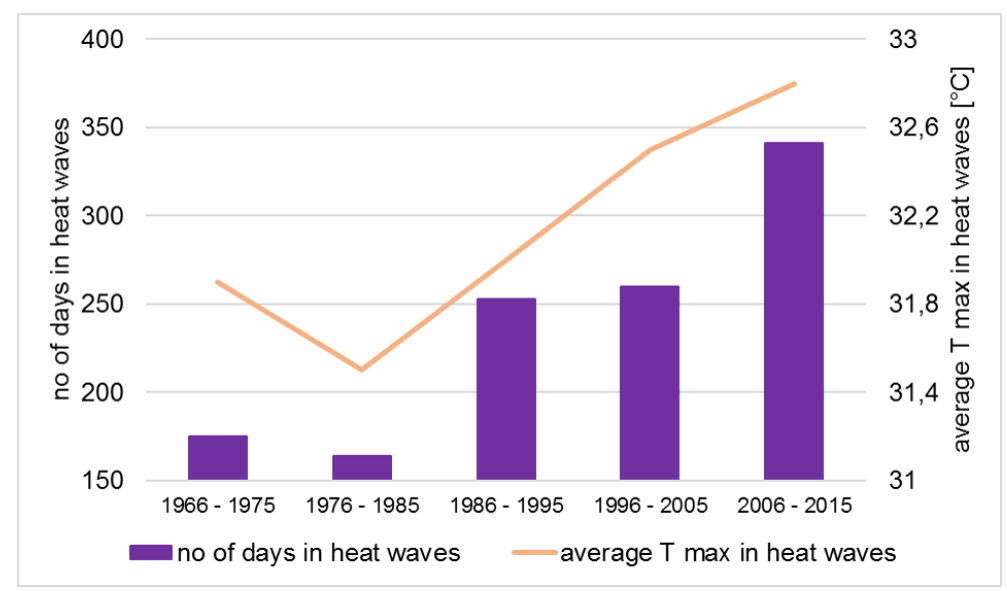

Figure 1: Decadal number of days (black) and average maximum air
temperature (gray) in heat waves (at least 5 consecutive days Tmax $\geq$
$29.5^{\circ} \mathrm{C}$ ) in years from 1966 to 2015 in Bilje(data: ARSO, 2016).

The hottest part of Slovenia is southwest. For example, in Bilje near Nova Gorica in 1960. and 1970. years in average 15 to 30 hot days (maximum daily air temperature equal or higher of $30^{\circ} \mathrm{C}$ ) were detected per year, while in last 15 years there was 35 to 50 hot days per year. In 2003 daily maximum air temperature was higher than $30^{\circ} \mathrm{C}$ every day between 15 July and 24 August. There is also an increase in the number of tropic nights (minimum daily air tempera- 
ture does not fall below $20^{\circ} \mathrm{C}$ ), which have a negative effect on sleeping and regeneration after a hot day.

The 5-year Heat-Shield project has started in 2016, so it is at the end of its first stage, analyzing current working conditions in the five sectors. Heat stress is readily associated with high environmental temperatures and humidities (Bernard and Cross, 1999), so WBGT (Wet Bulb Globe Temperature) index has been chosen as the most appropriate one to describe working conditions (Gao et al., 2017) and will be used for monitoring, climate change projections and monthly forecasts. Some measurements of conditions in the manufacturing plant are presented, followed by results of heat stress survey among workers at various workplaces.

\section{Methods}

Air temperatures are measured every 15 minutes at several workplaces in the manufacturing plant near Celje at 1.5 and $0.05 \mathrm{~m}$ height along with relative humidity at $1.5 \mathrm{~m}$. Measurements are carried out by Jozef Stefan Institute. Temperature and relative humidity data for 1 August to 20 August 2016 from one sensor at $1.5 \mathrm{~m}$ were used (the others have not work during last summer yet). WBGT index $\left[{ }^{\circ} \mathrm{C}\right]$ is calculated using Lemke and Kjellstrom (2012) formulation, following Bernard and Pourmoghani (1999). For in shadow/indoor conditions air temperature $\left(\mathrm{Ta}\left[{ }^{\circ} \mathrm{C}\right]\right)$ and dew point temperature $\left(\mathrm{Td}\left[{ }^{\circ} \mathrm{C}\right]\right)$; calculated from relative humidity) is used:

$$
\text { WBGT }=0,67 \mathrm{~T} \_ \text {pwb+o,33T_a, }
$$

where $\mathrm{T}_{\mathrm{pwb}}$ is a psychrometric wet bulb temperature (artificially created conditions with a wind speed of 3-5 m/s), determined by iteration from air and dew point temperature (equations in McPherson (2008)). Air temperatures at meteorological station Celje for the same period were obtained from Slovenian Environmental Agency.

Survey about heat stress at work, symptoms, health problems and their own solutions were made in the year 2016 among 808 workers using comprehensive questionnaires. Half of them are employed in manufacturing plant, $28 \%$ in agriculture (not necessarily their only financial source), $15 \%$ of participants work mainly in office (publishing house or Biotechnical Faculty), and $7 \%$ of them are tourist guides. Office workers were included for comparison although they do not belong in any of five sectors addressed by Heat-Shield. Men are prevailing only among agricultural workers $(62 \%)$, and women in other groups (65\% in manufacturing plant and offices, $52 \%$ in tourist guides). Groups are age-homogenous: $25 \%$ under 30 years old, $29 \%$ from 31 to 40 years, $25 \%$ from 41 to 50 years, and $21 \%$ over 50 years old. 


\section{Results and discussion}

Measurements in the manufacturing plant are showing very high temperatures during summer, but the situation is only a little better during the rest of the year. In the analysed period, the temperatures outside vary from 6 to almost $30^{\circ} \mathrm{C}$, but the temperatures at the workplace never fall below $22^{\circ} \mathrm{C}$ and rise up to $33^{\circ} \mathrm{C}$ (Figure 2). WBGT values are mainly between 20 and $25^{\circ} \mathrm{C}$, which is already high for moderate or heavy work, as heat stress management have to start around WBGT value of $25^{\circ} \mathrm{C}$ for heavy work (Gao et al., 2017).

Workers in this manufacturing plant are reporting thermal discomfort, especially if they need to wear specific clothes like thick black polo shirts, which are not a part of protective clothing. The effectiveness of our autonomic heat dissipation capacity is related to what type of clothing is worn and the environmental conditions (Lucas et al., 2014).

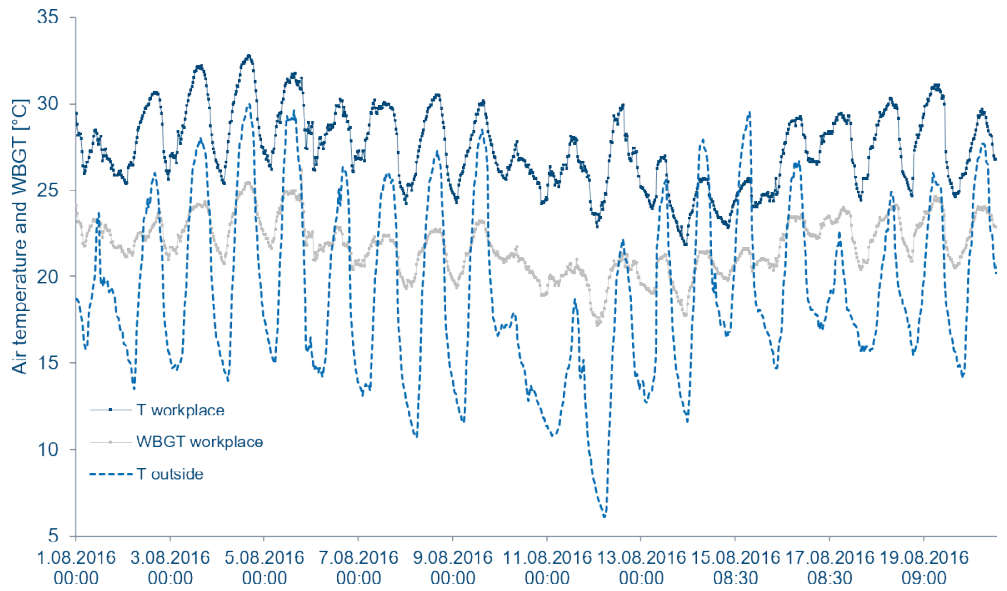

Figure 2: Working conditions in the manufacturing plant near Celje: measured air temperature at one workplace at $1.5 \mathrm{~m}$ height (T workplace), calculated WBGT index (WBGT workplace) and measured air temperature at meteorological station Celje (T outside).

In the manufacturing plant, the cooling system is not efficient enough due to injection molding machines as additional heat sources. For $20 \%$ of workers working conditions during heat waves are perceived as hot, for another $20 \%$ too hot, and for $45 \%$ extremely too hot (Figure 3). Tourist guides did not answer that question as they do not have a permanent workplace. Conditions are certainly better in offices, as $66 \%$ workers have air conditioning at their workplace and $11 \%$ in the vicinity. However, more than half of them did rate working conditions during heat waves as hot (or worse), and only for $20 \%$ workers is the temperature suitable, so air conditioning does not solve the problem as a whole. For $27 \%$ of agricultural workers is working outside during heat waves extremely too hot and for $36 \%$ too hot. There were no significant variations be- 
tween age groups even though with the aging of the workforce, it's resilience to heat stress degrades with further negative effects on health and productivity.

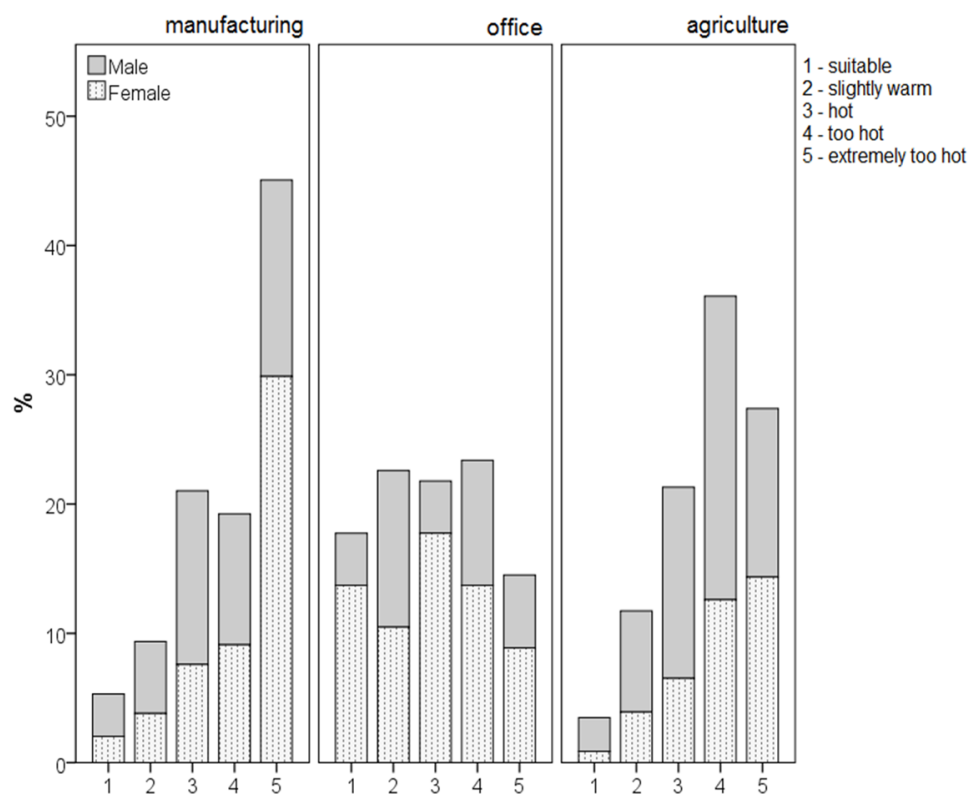

Figure 3: Thermal comfort at workplaces during heat waves (754 workers).

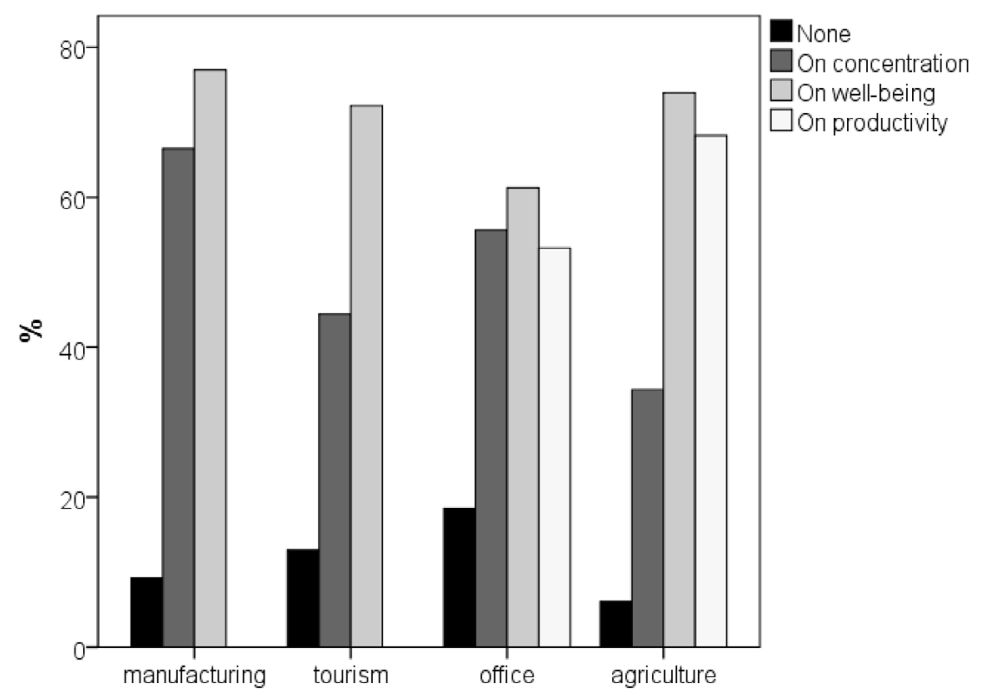

Figure 4: Perceived negative impact of hot working conditions during heat waves (808 workers). 
According to Lucas et al. (2014), occupational heat exposure threatens the health of a worker not only when heat illness occurs but also when a worker's performance and work capacity is impaired. Figure 4 gives a clear sign, how high is the negative influence of heat stress on various areas, although workers in the manufacturing plant and tourist guides did not have a choice of the answer 'impact on productivity' due to their working regime. Only $20 \%$ office workers and even fewer others think that there is no negative impact of heat. The highest assessed is the negative impact on well-being (6o-75\%), followed by the negative impact on productivity in agriculture $(68 \%)$ and by the negative impact on mental concentration in the manufacturing plant $(67 \%)$ and in offices (56\%).

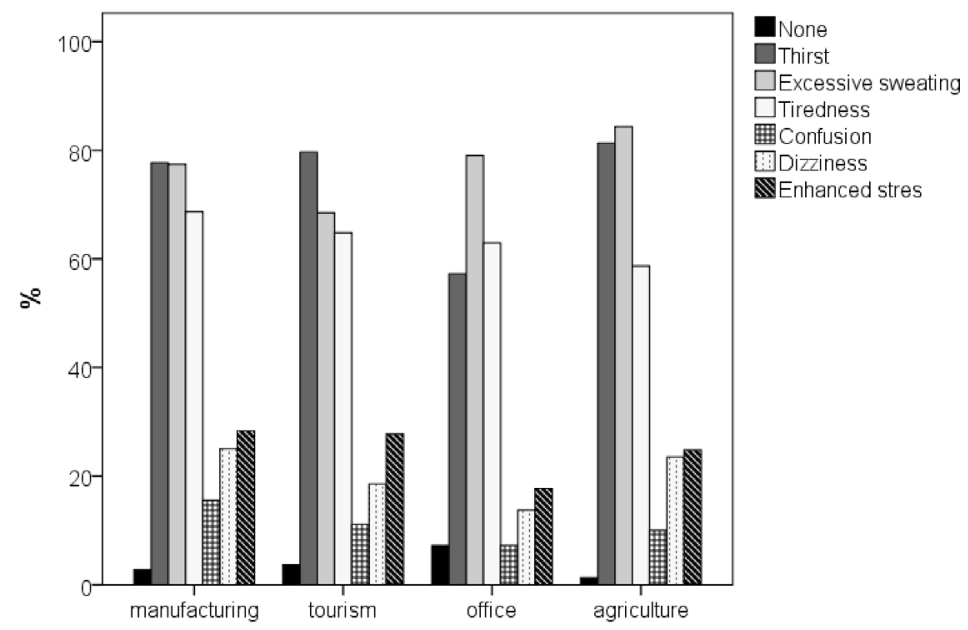

Figure 5: Perceived symptoms of heat stress during work in the summertime (808 workers).

The highest negative impact on well-being is well reflected in perceived symptoms of heat stress (Figure 5). Thirst and excessive sweating are common during summertime, but it can be seen that in the office is easier to drink regularly than at other workplaces. Around $60 \%$ of workers in each sector are tired because of heat stress, they are reporting also about enhanced stress and dizziness (15-30\%), and confusion (5-15\%). The latest three symptoms are the least expressed at office workers and comparable for the others.

Mild effects are certainly more common, but in extreme cases, people can get seriously sick or die. Among 808 workers have 31 already been hospitalized because of heat-induced health problems. The most common health problems in the manufacturing plant are a headache and exhaustion (more than half of the workers), and in other three sectors exhaustion - in agriculture, more than $60 \%$, followed by a headache (Figure 6 ). In tourism is the next problem prickly heat and in the manufacturing plant nausea or vomiting (more than 20\%). 
There have also already been problems with muscle cramps, fainting, and exceptionally heat cramps or even heat stroke.

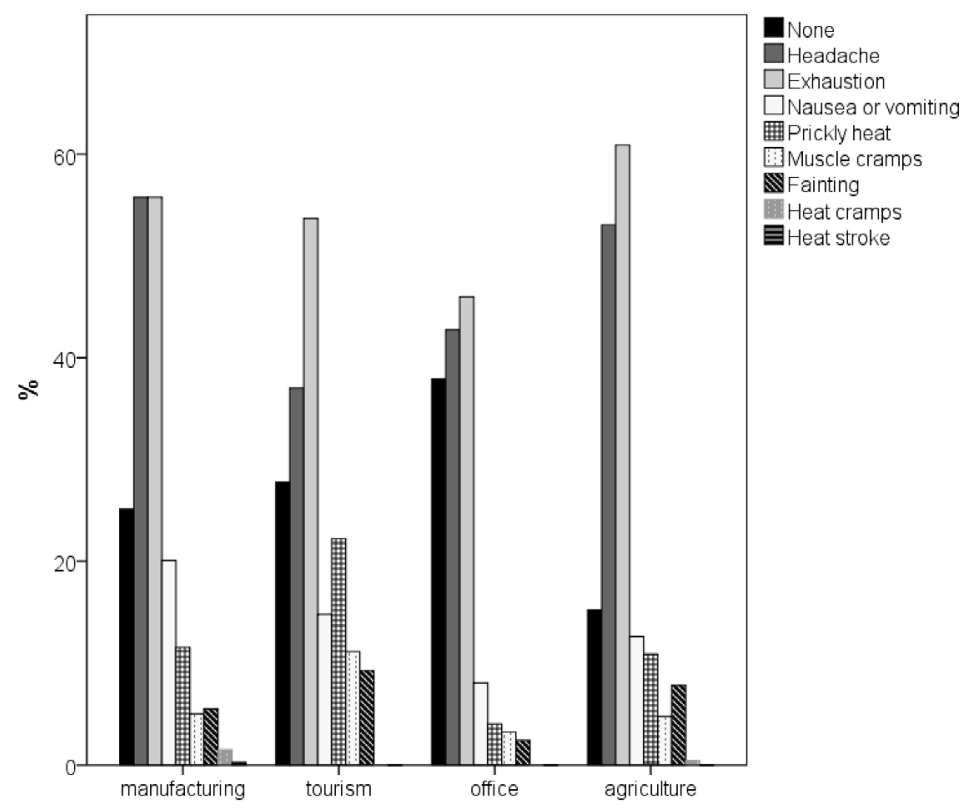

Figure 6: Heat-induced health problems experienced working during heat waves (808 workers).

To minimize excessive heat exposure in the workplace, it is recommended that workers and employers regularly review the potential impacts of heat on workers' health and productivity (Lucas et al., 2014), but this is not yet a common practice in Slovenia. There are some instructions published on the Labor Inspectorate web-site (IRSD, 2015) and for internal use on Chamber of safety and health at work (ZVZD, 2015). However, only workers in the manufacturing plant were in majority informed about heat stress impacts (4 out of 5), while $80 \%$ of office workers was not informed by the employer, and also $75 \%$ of tourist guides and almost $60 \%$ of agricultural workers did not get any heat-related warning by advisors. Mainly only agricultural advisors in Southwestern Slovenia have the necessary knowledge on heat stress and important precautions.

Anyway, workers try to help themselves by drinking more water (8o90\%). In agriculture, the majority of workers try to adjust their working schedule (70\%) and take breaks in a cooler space. In office and in tourism they try to wear appropriate clothes and in tourism also to take breaks in a cooler space (Figure 7). In the manufacturing plant, they have to follow many regulations and fulfill the working norm, so they have much less freedom in the choice of clothing, working schedule and breaks, therefore more than $20 \%$ of them answered that they cannot do anything to reduce the exposure to heat stress. 


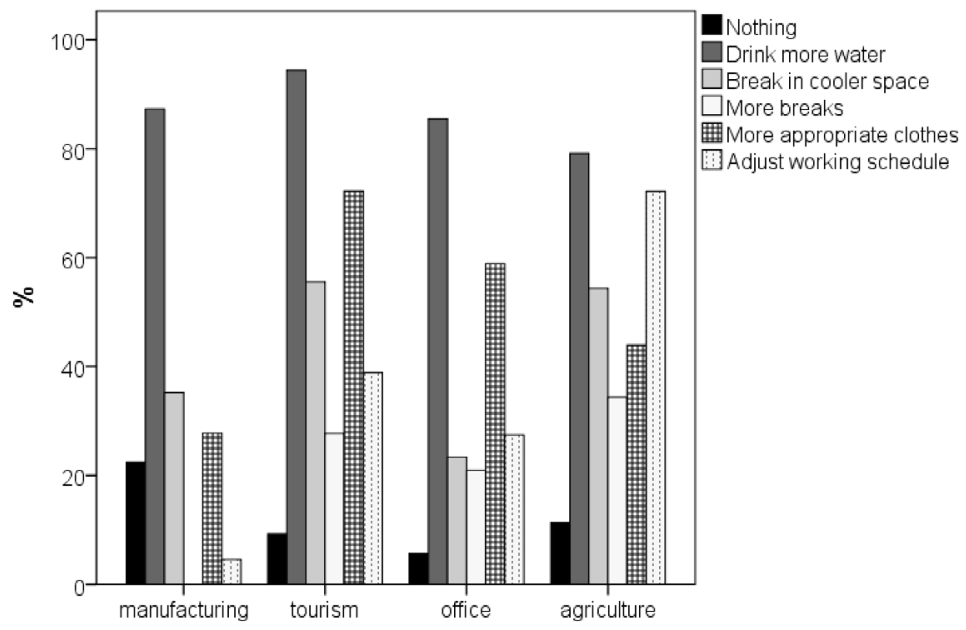

Figure 7: Workers' opinion (808), how one can reduce the exposure to heat stress.

\section{Conclusions}

In the field of heat stress negative impacts on workers' health and productivity is a major need for intersectoral collaboration. The knowledge that we already have or that we will obtain in further research needs to be transferred into recommendations so that employers can maintain health and productivity of their workforce. Among many themes that need to be addressed in the future is also the definition and analysis of heat waves, which is in progress in Slovenian Environmental Agency and Biotechnical Faculty. Even though summer temperatures do not seem extremely high in Slovenia, workers already report on heat stress at their workplaces. Climate change will bring a further increase in a number of hot days, which will worsen the heat stress working problems in Europe and also in Slovenia.

The survey among 808 workers has shown that there are some symptoms of heat stress very common among workers (thirst, excessive sweating, tiredness) and that they usually lead to a headache, exhaustion, nausea or vomiting, and prickly heat. Workers sense the negative impact of heat stress on their wellbeing, mental concentration, and productivity. In some cases, health problems even had to be cured in the hospital. However, apart from some web instructions, there has never been a serious campaign to inform employers and workers about heat waves and to propose solutions. This is also one of the further steps in the Heat-Shield project, where we will develop a warning system and test various solutions, depending on workplace specifics.

\section{Acknowledgments}

The work was supported by the European Union Horizon 2020 Research and Innovation Action (Project number 668786: Heat Shield). We are indebted to 
Profs. Igor Mekjavić, Lars Nybo, Andreas Flouris and Tord Kjellstrom for their assistance.

\section{References}

ARSO, 2014. Klimatološki trendi, Agencija RS za okolje [Date of access 5. 3. 2017]. Available at http://meteo.arso.gov.si/met/sl/climate/trends/

ARSO, 2016. Scenariji podnebnih sprememb, Agencija RS za okolje [Date of access 7. 3. 2017]. Available at http://meteo.arso.gov.si/uploads/probase/ www/climate/PSS/scenariji/letak_RCP45_2070.pdf

BERNARD, T.E. and CROSS, R.R., 1999. Case Study Heat stress management: Case study in an aluminum smelter. International Journal of Industrial Ergonomics, no. 23, pp. 609-620.

BERNARD, T.E. and POURMOGHANI, M., 1999. Prediction of Workplace Wet Bulb Global Temperature. Applied Occupational and Environmental Hygiene, no. 14, pp. 126-134.

GAO, C., KUKLANE, K., ÖSTERGREN, P.O. and KJELLSTROM, T., 2017. Occupational heat stress assessment and protective strategies in the context of climate change [in press]. International Journal of Biometeorolo-

gy. [Date of access 15. 5. 2017]. Available at DOI 10.1007/soo484-017-1352-y

HS (Heat-Shield project), 2016. Available at https://www.heat-shield.eu/

IRSD (Inšpektorat RS za delo), 2015. Ukrepi delodajalca ob visokih temperaturah na delovnem mestu [Date of access 3. 4. 2017]. Available at http:// www.id.gov.si/fileadmin/id.gov.si/pageuploads/Varnost_in_zdravje_ pri_delu/VISOKE_TEMPERATURE_-_PROMOCIJA/visoke_temperature_na_dm_sj_2015.pdf

LEMKE, B. and KJELLSTROM, T., 2012. Calculating Workplace WBGT from Meteorological Data: A Tool for Climate Change Assessment. Industrial Health, no. 50, pp. 267-278.

LUCAS, R., EPSTEIN, Y. and KJELLSTROM, T., 2014. Excessive occupational heat exposure: a significant

ergonomic challenge and health risk for current and future workers. Extreme Physiology and Medicine, no. 3 [Date of access 10. 3. 2017]. Available at https://www.ncbi.nlm.nih.gov/pmc/articles/PMC4107471/

McPHERSON, M.J., 2008. Subsurface Ventilation and Environmental Engineering, 2nd Ed., Ch. 17. Physiological reactions to climatic conditions. Mine Ventilation Services Inc., Clovis [Date of access 25. 11. 2016]. Available at http://www.mvsengineering.com/index.php?cPath $=25$

WHO (World Health Organisation), 2015. Available at http://www.euro.who. int/en/health-topics/environment-and-health/occupational-health

ZVZD (Zbornica varnosti in zdravja pri delu), 2015. Toplotno okolje na delovnem mestu (ZZZS in ZVZD): Neuradni prevod navodil za toplot- 
no okolje na delovnem mestu HSE, Velika Britanija [Date of access 14.

4. 2017]. Available at: http://www.zbornica-vzd.si/media/Toplotno\%2o ugodje-\%2oUK\%2osmernice_06_07_2015.pdf 